\title{
13.TRANSFIGURATIONS AND INTERFERENCES OF THE BALLAD MASTER BUILDER MANOLE WITH THE OPERA GENRE. CHORAL POLYCHROMIES
}

\author{
Consuela Radu-Țaga ${ }^{113}$
}

\begin{abstract}
One of the fundamental myths of the Romanian literature, Master Builder Manole had various approaches in the opera genre. On individual stylistic paths as musical language and show formula, Alfred Mendelssohn, Gheorghe Dumitrescu, and Sigismund Toduță reinterpreted the myth of the human sacrifice, in an extremely nuanced approach of the transfiguration of the ancient folklore. The choral inserts are polychromatic, having different forms and formulas: men choir, female choir, mixed choir, choral conglomerations. The three composers wrote a romantic music, in terms of content, and a classic one, in terms of the formal elements themselves.
\end{abstract}

Key words: Master Builder Manole, human sacrifice, Romanian opera, choir, ancient folklore

\section{Introduction}

The Romanian folk ballad Master Builder Manole was collected by Vasile Alecsandri and it is several centuries old. The theme of creation through selfsacrifice is one of the oldest myths of the humankind, reminiscent of the Olympian spirit of the ancient Thracian Myths, Oedipus and Orpheus. From the perspective of the major reason of the Romanian spirituality, with enlightened valences for the whole cultural image, the ballad also experienced musical transfigurations, having a certain influence on the composers, including George Enescu. Iacob Mureșianu was the first to approach the old legend, leaving us the cantata The Monastery on the Argeș River, who opened a path on which Alfred Mendelssohn registered Master Builder Manole opera. Gheorghe Dumitrescu and Sigismund Toduță went on to capitalize the same theme, through the prism of their own visions with specific means, enriching the Romanian opera repertoire. The operas Master Builder Manole are not sung nowadays but they are waiting to be (re)discovered and (re)interpreted.

\section{The Lyrical Drama Master Builder Manole by Alfred Mendelsohn}

On the path of exploring Romanian myths, Alfred Mendelsohn enroled his lyrical drama Master Builder Manole, on a libretto signed by Alexandru Jar, after the legend with the same title. Placed in the Romanian inter-war avant-garde, the composer with Viennese studies turned to the lyrical genre, his first opera, Master Builder Manole being realized in 1949. The sacrifice of Manole's wife, incorporated alive into the walls of the monastery, was presented and developed in three acts and six tableaus.

When the curtains are rising, the masons sleep on the scaffolding, which is musically translated into closed mouth singing. The collaps of the monastery's walls wakes them up, and the confused people rush to one side and to the other.

\footnotetext{
${ }^{113}$ Lecturer PhD., "George Enescu” National University of Arts from Iaşi, Romania, email:
} 
The clash of the moment is musically rended through the participation of three men groups: two groups call down the wrath of God on the stage, and the third sings vocalize in coulisse. The result is a dense musical construction that takes place in pesante tragicamente, a texture that plays with maximum efficiency the dramatic moment, the confusion of the people and the imposition of divine force:

Pesante tragicamente

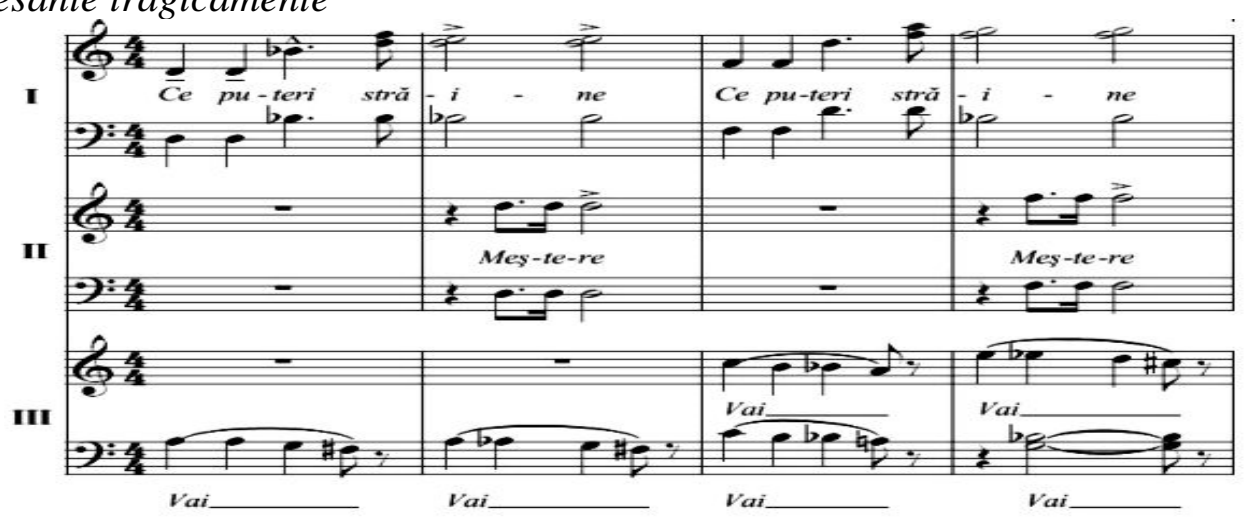

Fig. 1. Alfred Mendelsohn - Master Builder Manole, first act, first tableau

Determined to continue building the monastery, the masons get to work. The second tableau presents the image of a new attempt to built; the urge to work is not lacking popular singing, the men choir divided on 4 voices vigorously affirming a chordal structure. But the entire effort is in vain; the monastery does not rise. On the principle of contrasts, the point of interest is heading towards the painting of a popular feast. During their breaktime, somewhere near the cathedral, the masons and the workers are resting, while women and the girls rejoice besides the peasants. It's a good opportunity to introduce a new mixed chorus Cântă inimioarăa, cântă $\breve{a l}^{114}$, followed by a goliardic song:

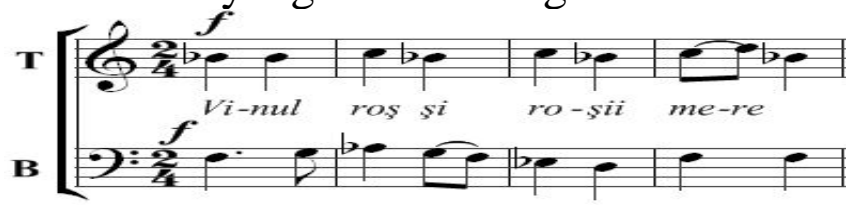

Fig. 2. Alfred Mendelsohn - Master Buider Manole, third act, fifth tableau

By the sacrifice of the beloved woman, the human soul is transferred into the new building, into the artistic creation. The light goes down on sixth tableau, the cathedral rises into the sonority of the mixed choir, with the internal voices divided, on a high dynamics (ben forte, fortissimo).

\section{The Ballad-Opera Master Builder Manole by Gheorghe Dumitrescu}

The Romanian Myths Cycle, extensive musical construction accomplished by Gheorghe Dumitrescu, also contains the ballad-opera Master Builder Manole. The personal interpretation of the myth of creation with the price of the human sacrifice took shape between 1969-1970, the fecund composer signing not only the music, but also the libretto. The opera is one with grand amplitude (it lasts about four hours), having lyrical-meditative accents, which transfigurates the fundamental pattern of the oral tradition. The dramatic legend is structured in four acts (seven tableaus), and appearances of the nine masons (men vocal group) and the choral ensemble are major background elements.

The first choral configuration belongs to the men ensemble, the canon 
between tenor and bass voices in andante maestoso stating the qualities of the Master builder. The tableau entitled Loc de mănăstire ${ }^{115}$ calls upon the wide sonority of the mixed choir, while the unison with harmonic vertical infiltrations, in E Major, illuminates the moment of greeting of Neagoe Vodă, the ruler of Wallachia. The next tableau is marked by the emergence of the particular timbre of the women choir (first sopranos, second sopranos, altos), a surface thought as a lyrical respiro. The wives and the sisters of the masons, which are carrying baskets with victuals, can be seen from a far. Andante tranquillo introduces a canon in pianissimo, the gradual approach of the collective character requiring the singing in the backstage.

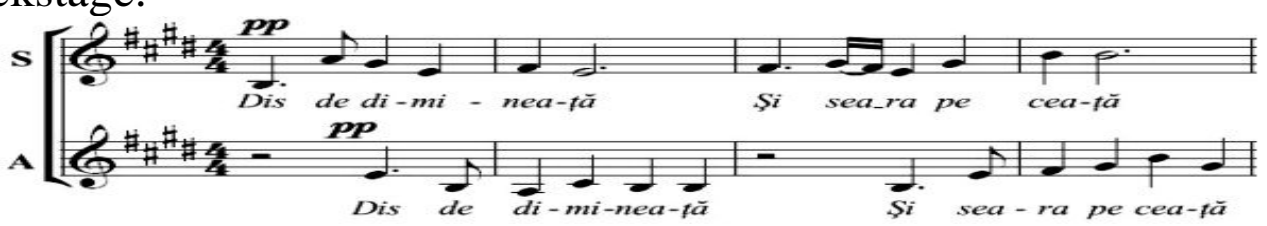

Fig. 3. Gheorghe Dumitrescu - Master Builder Manole, second act, second tableau

In the third act, the mixed choir represents the forces of nature, who are trying to stop Ana from getting closer. In this moment a vocalise with polytonal insertions emerges. Later, on Easter day (in the forth act), after the monastery was built, the choir of priests sings a song in the backstage, a song which is a part of the consecration ceremony of the new monastery, because the church carries inside the sacrament of the heavenly Jerusalem, and it gets us ready for the Resurrection and for the Easter:

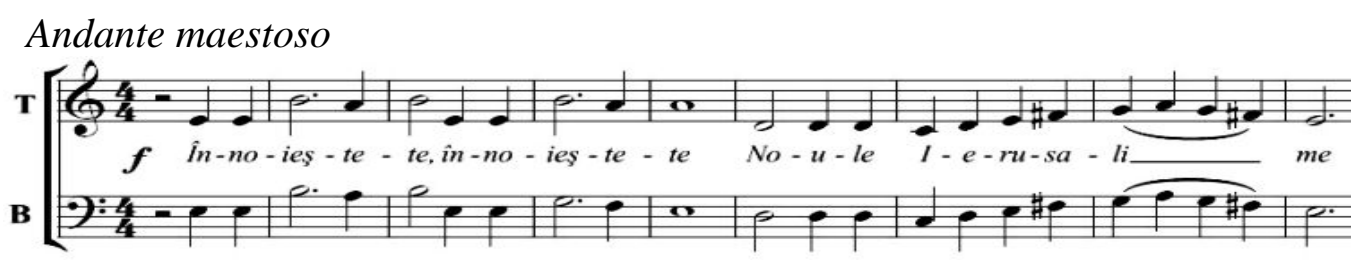

Fig. 4. Gheorghe Dumitrescu - Master Builder Manole, fourth act, fifth tableau

The end of the opera is treated choral and orchestral, and andante maestoso launches the sonorous structures on the $a$ vocal, on a high note, having ascending seconds and thirds on an elevated dynamics, graduated up to the climax of fortissimo. Each choral section is divided, resulting a vertical conglomerate disposed on eight voices. The epilogue brings serenity to the musical text, the mixture of the sonours beams in the medium register, brightly coloured, with ostinati passages in low and high register, prepares a coda with iridescent sonorities, a coda full of finesse in its structure from within.

\section{The opera-oratorio Master Builder Manole by Sigismund Toduță}

Sigismund Toduță explored the Romanian mythical universe in operaoratorio Master Builder Manole. The drama had a vague outline between 19431947, beeing version based on the libretto made by the pianist Ana VoileanuNicoară. The composer came back to the score between 1978-1983, and proceeded to the double elaboration, of the music and also of the libretto, capitalizing the abstract-philosophical consistency of Lucian Blaga's masterpiece, which assimilated the content of the popular ballad. Maestro Toduță resorted to the compression in the dramaturgy of Blaga, the fifth acts of the play beeing musically

${ }^{115}$ Monastery place (t.a.C.R.T.) 
transposed only in three. "Essentialised, filtred out by the external elements, emphasizing the inner drama of the heroes, Master Builder Manole by Sigismund Toduță represents, we believe, after Oedipus, the most significant moment of our musical culture" 116 [5, p. 9].

The choral ensemble is widely used, in different forms: the men choir represents the musical overcollateralisation of the craftsmen group (the masons); the formula of the mixed choir expresses the visionary lament of Găman, and actively participates to the culminating episodes of the third act; women choir has a token role, and is inserted with byzantine sonorities in the extreme acts. The musical development requests the contribution of three characters distributed to the singers (Manole - baritone, Mira - lyrico-dramatic soprano, the prior Bogumil - basso cantante), to which are added a reciter - baritone (Găman). Entirely focused on the struggle of the character, the first act is outlined as a expositive section, with pronounced scenic availabilities. The first choral occurrence goes to the masons in the backstage: tempo giusto, 6/8. The exclamations give rise a precise intonation, with slides from a pitch to another, on a distance from second to fourth, resulting the image of the construction which decomposes:

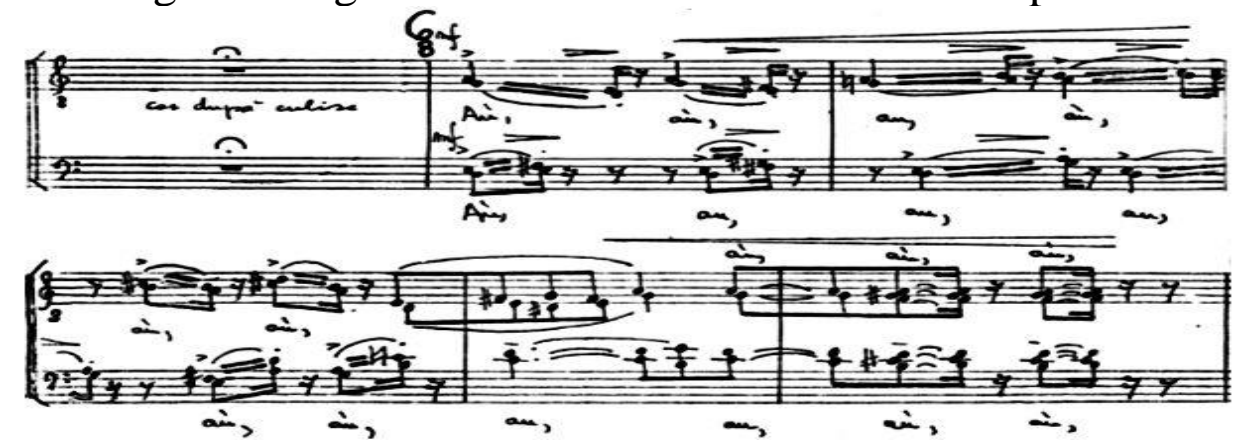

Fig. 5. Sigismund Toduță - Master Builder Manole, first act

Shortly, Găman is interrupted by the sonority of the mixed choir (also in backstage), with suggestion of ghosts, voices from beyond this world, malefic spirits. The male voices go in parallel lines, resulting sonorous units, and the female voices go from declamation, sounds marked with crosses, to precise intonation. The tenors and basses barrows the declamation on a descendent passage in staccato - technical procedure that expresses amusament; this figure is also taken over by the hole choral mass.

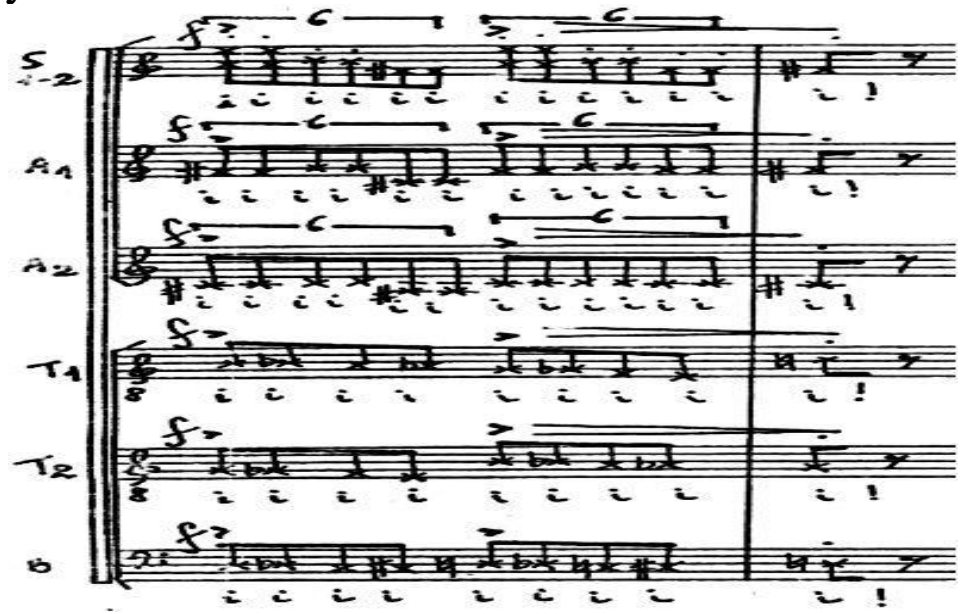

Fig. 6. Sigismund Toduță -Master Builder Manole, first act

Manole is hopeless, but he dasn't give up, because the demon from within 
him cried out: sacrifice! It is the moment when the girls choir (first and second sopranos, first and second altos) sing à cappella an anthem in Greek - Protipokeon ton sta vron su Hristeke tiis engo niis evloghiam harizomenos ${ }^{117}$. The solemn choral structure will be retraced in the end of the third act, after the masons were finished building Mira alive, when the musical discourse gives up the à cappella expression, but it keeps the ideea of great simplicity through the choral unison.

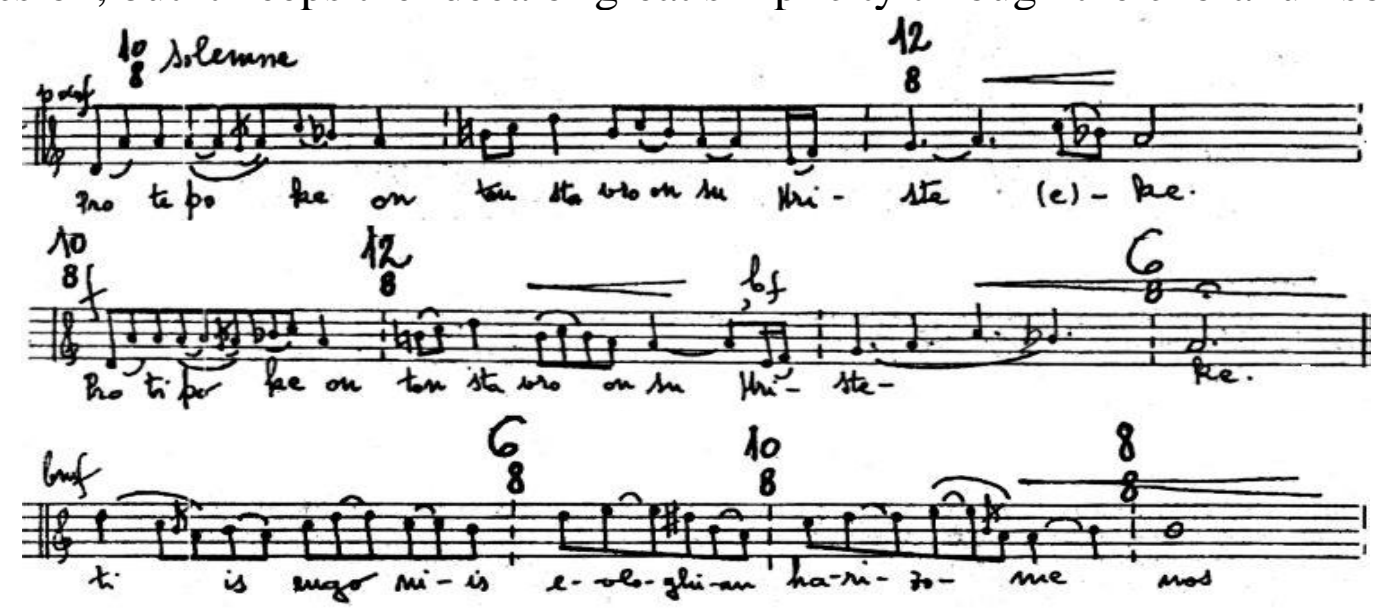

Fig. 7. Sigismund Toduță - Master Buider Manole, third act

The appearance of the female character provides an opportunity to develop beautiful musical pages, where the voices of Mira, Manole, and Găman are incorporated. The composer indicates a free fugue in the moment when the masons enter the stage. This way it results an ample juncture with reigning mastery, interpreted in staccato sempre e molto leggiero, a moment where the male choir is divided in six sections: first, second and third tenors, first and second baritones, and basses. Those in charge for guarding the edification decided to give up, and live the place that was falling apart. From the sounds with determined intonation, to parlato, with glissando, sforzato accents, the musical image is extremely expressive, the episod being one that is particulary difficult for the choristers.

The final representation of the collective character from the second act brings back the mixed choir formula. The ascendent leap on glissando stands out, starting from a determined sound, leading up to both determined and indefinite sounds. The figure makes us think of alphorn sonorities, because the ideea of incantation is also insinuated by the reserved layout to the reciter Găman.

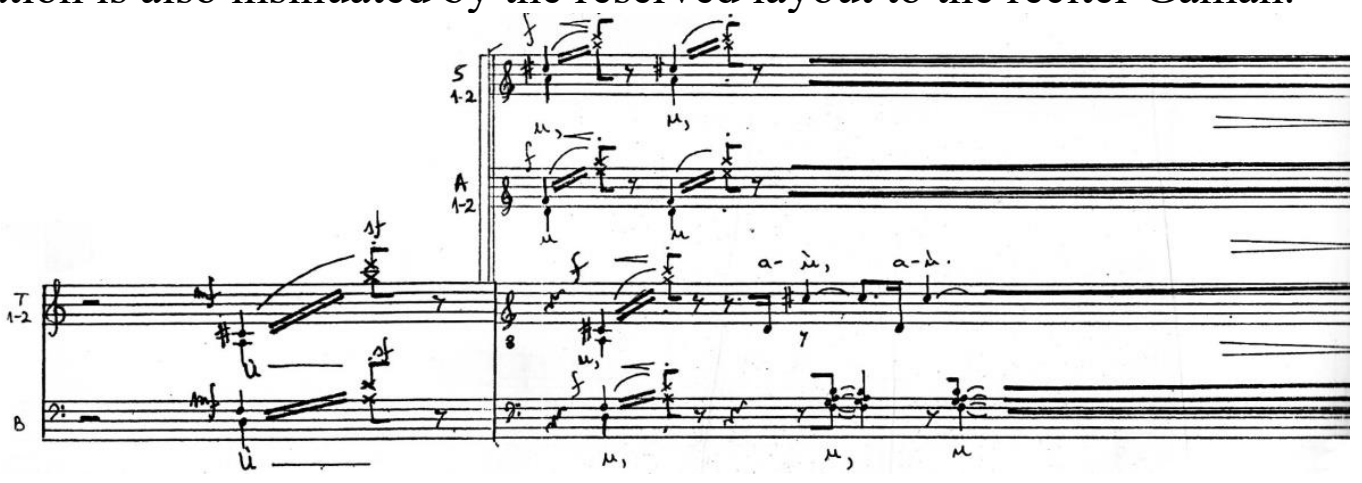

Fig. 8. Sigismund Toduță - Master Builder Manole, second act

In the second act, Manole and his companions go through various emotional states: anxiety, doubtless, determination. The range of creation techniques enriches through the alternation between the free poliphony of the orchestra and of the men

${ }^{117}$ In the beginning still burning on your cross, Christ, and giving blessing to the descendants (t.a.C.R.T.) 
choir, with moments of stretto. From the masons group which is the storyteller in this case, we fiind out that the Master builder wonders through the country for seven years, trying to build a church; confused, Manole is not sure if he can trust his own forces and skills anymore, or if he is forced by the circumstances to pray to God. With one eye he measures, with another he prays. Every section of the ensemble is divided by two, while the dramatic clanching appeals to the polyphonic takeover. The ideea of the prayer marks the beginning of a fragment interpreted in piano monotono, the basses in rilievo overlay the binary and ternary pulsation, over the other voices, while the orchestra joins the sonority through the performance in mormorato.

The epic drama crosses paths with the direct participation of the collective character, who is investigating the foundation of the construction. Descovering the truth, Manole calls upon the people să pună gaz nerăbdării ${ }^{118}$, but they exclamate instead:

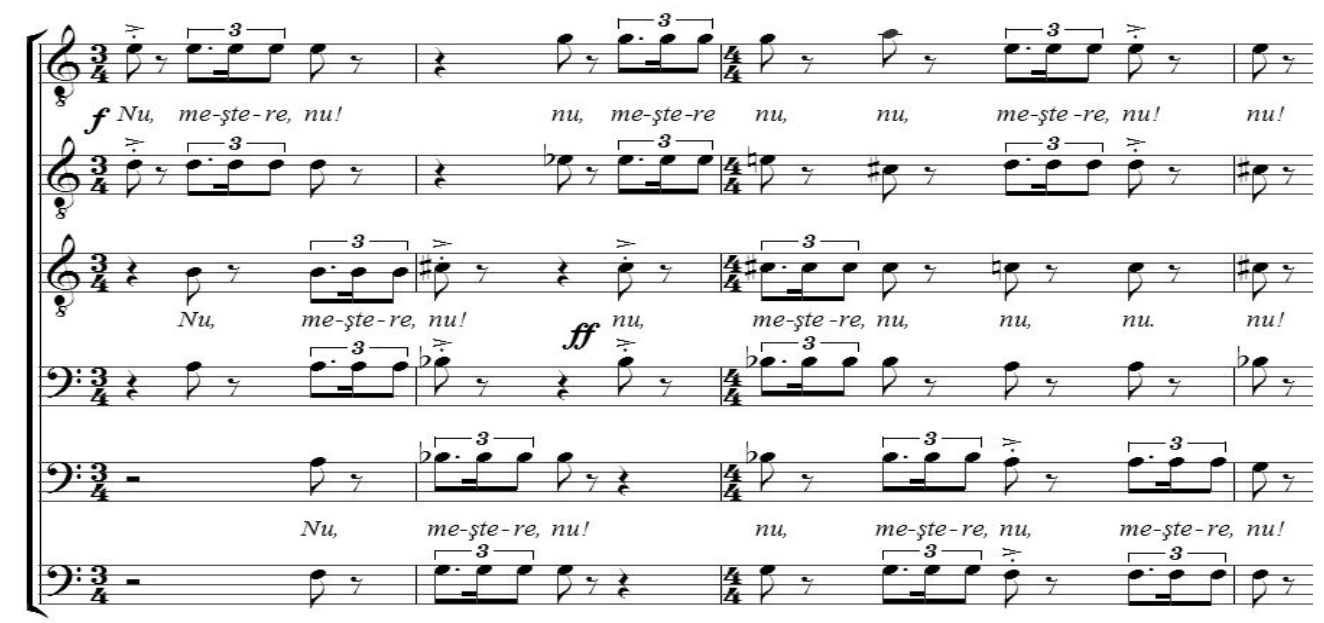

Fig. 9. Sigismund Toduță - Master Builder Manole, second act

Shortly after, the choristers open a fugatto. Multiplying a unique thought, they firmly express their decision to live the place. The rebelion of the masons despleases Manole. In the furious opening (quasi gridando), the Master builder calms himself down and explains to the people the fact that he has a purpose: to create. The new intervention of the men choir uses the imitation procedure on a descending path. The augmented second and the mordent infiltrate themselves in the melodic dimension, being elements retrieved from folklore. The following ascension of the choral episode creates tension, while the dynamics in piu forte, with crescendo require the effort of the abdominal musculature of the choristers. They take a short breath and they start the men unison in piano. It must be outlined the enhanced focus of the basses, while singing $\mathrm{E}$ in the high register. The recitative singing separtes the voices in a fan shape, a detachment sustained also by the increase of the intensity. The symphonic blast accompanies the vow scene established on the foundation of an ostinato bass, which containes four sounds.

Through sacrifice the people achieve the miracle they needed to build the church. The utterance of the word miracle brings to the choir the most reduced nuance from the entire score: pianississimo with a precise intonation, but almost whispered. The same manner of emission is kept also when the tenors interfere, taking over from Manole the ideea of sacrificing the person they love the most.

\footnotetext{
${ }^{118}$ to burn the impatience (t.a.C.R.T.)
} 
The soft development in pianissimo requires a moment of grieving, the crying being suggested through the figure of the descending leap in glissando.

The gradation of the dynamics is made progressively from pianissimo, through mezzoforte, ben mezzoforte, finaly reaching forte. The craftsmen can't get rid of the curse that has come upon them, unless they build alive a chaste woman. But who is going to be this woman? The atmosphere of restlessness is depicted through the pulverization of the dramatico-musical discourse, which switches from a voice to another, resorting again to moments of declamation. The decision that the all participants present in this particular scene agreed upon is enhanced by the affirmation $\operatorname{amin}^{119}$. The motif is distributed to the lower voices, to have more consistancy, and at the same time softness. The descending melodic path, with a conclusive appearance, arouses the presence of the ornaments, this time being retrieved from the byzantine music - the mordent is being used in the first exposition, while in the second the inferior appoggiatura appeares.

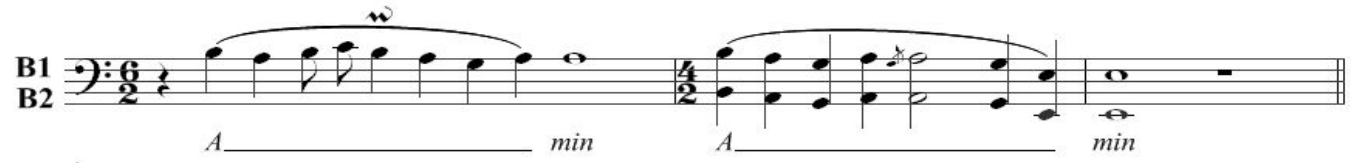

Fig. 10. Sigismund Toduță - Master Builder Manole, second act

Waiting to see which woman will be the one meant to be the supreme sacrifice, the masons are engaged in different remarks - they feel like someone is watching, but in fact the only things present are the shadows of the trees. To provide the flow of the action, the melody is carried from a voice to another, in a convenient nuance, mezzoforte.

The third act debutes with the reappearance of Mira. The moment of the church edification appeals to the mixed choral ensemble. Zvârliți tencuiala pe coapse și os/Să-nchidem viața în zidul de jos ${ }^{120}$ - these are beautiful spoken words interpreted by the choir in parlando romoroso. The mixture of the voices with a determined and undetermined intonation, the attack in staccato, the presence of the sforzato accents, the responses between soprano-alto and tenor-bass build a unique moment of madness. Between Mira's thunderous sounds of the innumerable plains, the voices of the choir can be heard, the girls singing in forte, even in the medium register. It results a sonority that must be balanced through the men's vocal forces, located in the transition passage towards the high register.

Four episodes intonated à cappella are delineated by the composer through the quasi choral indication, on a slow movement. The first three start from a unison, later developing an harmonical passage on four voices. The first secquence start from B center, in piano, the second from C sharp in mezzoforte, and the third from $\mathrm{E}$ in ben forte. The last episode, come un soffio, brings back the peace, all of the six female voices singing in piano - first, second, and third soprano; first, second, and third alto. The men voices, which are devided also in six, respond, the dynamics grows up to mezzoforte, while the female voices descend slowly and vibrate lightly (poco percettibile), their withdrawl being in morendo. It produces an effect of long plaints:

\footnotetext{
${ }^{119}$ Which means so be it

${ }^{120}$ Lash out the plaster on the hips and boun/ Lets lock the life in the wall of the bottom (t.a.C.R.T.)
} 


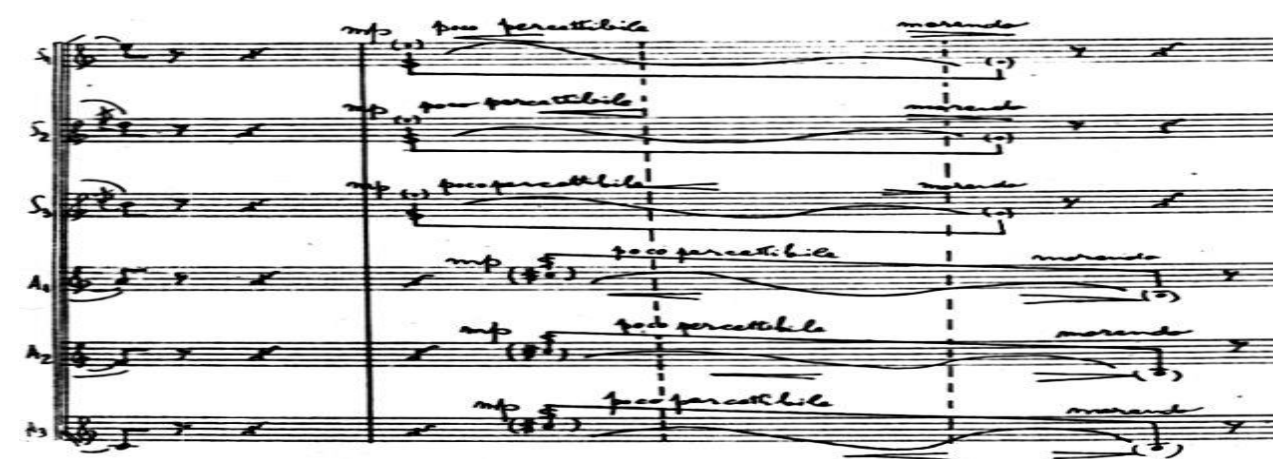

Fig. 11. Sigismund Toduță - Master Builder Manole, third act

The end of the opera belongs to the choral ensemble, with sonorous edifications from the choir of the masons. The byzantine melody reappears, being full of the archaic perfume of the female voices, while the mixed choir sing lines penetrated not only by profound pain, but also by philosophical meanings, like: Doamne, ce strălucire aici și ce pustietate în noi ${ }^{121}$ ! The final choir built on thematic chord A-B-D-E is intermittently accompanied by the sound of semantron and bells. The modal scale rotates around $\mathrm{E}^{122}$, sound that was the foundation of the musical construction. The orchestral timbre mentioned serve and create an autochthonous atmosphere of the musical language, the same way as aulodic element, the Romanian whistle of the antique tragedy was depicted through the oboe's solo.

\section{Conclusions}

In these three opuses, the balladic spirit lives and thrills from the first audition, the composers capture a romantic music, through the aspect of the substance, and at the same time a classical one, through the architectural elements. The choral ensemble couldn'n be absent from the diverse musical scenic transfigurations of the Master Buider Manole ballad, and the formulas which the composers use are varied: men choir (the masons), female choir (the wives), mixed choir, conglomerations of choral groups. The autochthonous timbre, impossible to be mistaken, reveals a modal world, where the choral virtuosity signs up on a path of sobriety, opened by the ancient theatre. All of the three scores stand out through expressiveness, suggestive character, even pictorial of the musical language.

\section{References}

1. Dumitrescu, G. (1970). Meșterul Manole [Master Builder Manole], reduction cantopiano, copy after manuscript. Craiova: Opera Română

2. Gherman, L. (1990). Revenire la o capodoperă: Meșterul Manole de Sigismund Toduță, Muzica no. 4 Magazine. București: Editura Muzicală

3. Mendelsohn, A. (1949). Meșterul Manole [Master Builder Manole], general score, copy after manuscript. București: UCMR

4. Toduță, S. (1983). Meșterul Manole [Master Builder Manole], reduction canto-piano, copy after manuscript. Cluj-Napoca: Academia de Muzică Gheorghe Dima

5. Țăranu, C. (1986). Meșterul Manole de Sigismund Toduță, Muzica no. 6 Magazine. București: Editura Muzicală

\footnotetext{
${ }^{121} \mathrm{O}$, God, what a brightness is here, and what a desolation is in our hearts! (t.a.C.R.T.)

${ }^{122}$ Cornel Țăranu named E the primer sound in the article Master Builder Manole of Sigismund Toduță, which was published in Muzica Magazine, no. 6/1986
} 